\title{
Response: Commentary: Variability in Shelf Sedimentation in Response to Fluvial Sediment Supply and Coastal Erosion Over the Past 1,000 Years in Monterey Bay, CA, United States
}

\author{
Joseph Carlin ${ }^{*}$, Jason Addison ${ }^{2}$, Amy Wagner $^{3}$, Valerie Schwartz ${ }^{2}$, Jamie Hayward ${ }^{1}$ and \\ Victoria Severin ${ }^{1}$
}

${ }^{1}$ Department of Geological Sciences, California State University, Fullerton, CA, United States, ${ }^{2}$ U.S. Geological Survey, Geology, Minerals, Energy, and Geophysics Science Center, Menlo Park, CA, United States, ${ }^{3}$ Department of Geology, California State University, Sacramento, CA, United States

Keywords: shelf sedimentation, littoral sand, coastal erosion, dams, climate, grain size, Monterey Bay, California

OPEN ACCESS

Edited by:

Steven L. Forman,

Baylor University, United States

Reviewed by:

Gary E. Stinchcomb,

Murray State University, United States

*Correspondence:

Joseph Carlin

jcarlin@fullerton.edu

Specialty section:

This article was submitted to

Quaternary Science, Geomorphology and Paleoenvironment,

a section of the journal

Frontiers in Earth Science

Received: 18 December 2019 Accepted: 20 May 2020

Published: 23 June 2020

Citation:

Carlin J, Addison J, Wagner A, Schwartz V, Hayward J and Severin V (2020) Response: Commentary: Variability in Shelf Sedimentation in

Response to Fluvial Sediment Supply and Coastal Erosion Over the Past

1,000 Years in Monterey Bay, CA,

United States. Front. Earth Sci. 8:210.

doi: 10.3389/feart.2020.00210

\section{A Commentary on}

Commentary: Variability in Shelf Sedimentation in Response to Fluvial Sediment Supply and Coastal Erosion Over the Past 1,000 Years in Monterey Bay, CA, United States

by Warrick, J. A., East, A. E., Storlazzi, C. D., and Conrad, J. E. (2019). Front. Earth Sci. 7:256. doi: $10.3389 /$ feart.2019.00256

We thank Warrick et al. (2019) for their interest in our Monterey Bay (MB) research (Carlin et al., 2019) and welcome the opportunity to further clarify components of our work. Warrick et al. (2019) contend that our conclusion that changes in the littoral sand fraction (LSF; \%sand fraction $>180 \mu \mathrm{m}$ ) reflect coastal erosion was "speculative at best, and very likely incorrect" and offered alternative sources and mechanisms to explain the data. We counter that, while our conclusion was speculative, it was consistent with our empirical data, and the alternative explanations they presented are no more viable than those we explored in our original publication (Carlin et al., 2019).

First, Warrick et al. (2019) argue there are other shelf features that could be a source for "littoral" sand as opposed to coastal erosion such as bedrock reef aprons, rippled-scour depressions (RSD), sand waves, and the outer shelf. We contend it is not certain that littoral-sized material is remobilized from these features, and for the sake of brevity will focus on RSDs as Rosenberger et al. (2019) found that remobilization from RSDs in $<25 \mathrm{~m}$ water depth was primarily limited to the fine-grained cap (fine sands and silts) not the coarser sediment. If only the fine-grained sediment is remobilized from these shallow water depths, it seems unlikely that coarser littoral-sized material will be remobilized from deeper shelf features. By contrast, coastal erosion is documented in MB (Hapke et al., 2009) with area beaches containing at least 90\% littoral-sized material (Best and Griggs, 1991), so coastal erosion is likely to remobilize littoral-sized material. While there are other potential shelf sources for "littoral" material, we feel that coastal areas provide the combination of source and setting where this material is most likely to be remobilized.

Warrick et al. (2019) also argue our study did not provide a credible transport mechanism. Sediment transport analyses were beyond this study's focus, which was to interpret sedimentary deposits in cores. Yet we did support our interpretations with examples from the literature which note that cross-shelf transport can be a sink for littoral material (e.g., Komar, 1996), and highlight where coastal erosion resulted in sediment transport to mid-shelf regions (e.g., Zhou et al., 2014). 
Furthermore, the alternative transport mechanisms proposed by Warrick et al. (2019) are inconsistent with our data based on the following arguments:

(1) The alternative mechanisms such as internal waves, biological activity, and fluvial-to-shelf transport are based on the climactic North Pacific regime shift in the mid-1970s that increased water temperatures and fluvial discharge (Warrick et al., 2019). Our data shows total sand (climate indicator) increases with this shift, but there is no significant change in the LSF (erosion indicator) at this time. These alternative mechanisms could increase total sand (which is consistent with our data), but we cannot attribute the changes in the LSF to these mechanisms because the data does not show a statistically significant change at that time.

(2) For trawling, from 1981 to 2000 the number of vessels using trawl gear in the Monterey Bay National Marine Sanctuary (MBNMS) remained relatively constant (Starr et al., 2002), and from 2009 to 2015 there was a decrease in trawling intensity and spatial extent within the MBNMS (Office of National Marine Sanctuaries (ONMS), 2015). Based on these data we contend that at best trawling activities remained constant or even decreased when we observe increases in LSF. The observed increases in LSF seem unlikely to result from trawling which remained unchanged or declined during this time.

Additionally, Warrick et al. (2019) contend our conceptual model presented is oversimplified and inconsistent with other systems. Our model may be oversimplified, but it was empirical and meant only to describe MB sedimentation. While it may not work for the Eel River as Warrick et al. (2019) point out, it is consistent with our observations and other studies showing sand loads increase in $\mathrm{MB}$ area rivers during elevated discharge (Gray et al., 2014, 2015; East et al., 2018).

We also feel the impact from dams was misrepresented by Warrick et al. (2019). Sediment reduction to the Santa Cruz littoral cell from dams was only $3 \%$, but the reduction from dams to the Southern MB littoral cell was 33\% (Willis and Griggs, 2003). The southern MB shelf is an important erosion area in our study, and we specifically used a core offshore of the Santa Cruz

\section{REFERENCES}

Best, T. C., and Griggs, G. B. (1991). "A sediment budget for the santacruz littoral cell, California," in From Shoreline to Abyss, ed R. H. Osborne (Tulsa, OK: SEPM Society for Sedimentary Geologists), 35-50. doi: 10.2110/pec.91.09.0035

Carlin, J. A., Addison, J. A., Wagner, A., Schwartz, V., Hayward, J., and Severin, V. (2019). Variability in shelf sedimentation in response to fluvial sediment supply and coastal erosion over the past 1,000 years in Monterey Bay, CA, USA. Front. Earth Sci. 7:113. doi: 10.3389/feart.2019.00113

East, A. E., Stevens, A. W., Ritchie, A. C., Barnard, P. L., Campbell-Swarzenski, P., Collins, B. D., et al. (2018). A regime shift in sediment export from a coastal watershed during a record wet winter, California: implications for landscape response to hydroclimatic extremes. Earth Surface Proc. Landforms 43, 2562-2577. doi: 10.1002/esp.4415

Gray, A. B., Pasternack, G. B., Watson, E. B., Warrick, J. A., and Goñi, M. A. (2015). Effects of antecedent hydrologic conditions, time dependence, and climate littoral cell as a "control" case where we observed no significant changes in the LSF, arguing this was due to a limited impact from dams in this area. Our conclusions were based on this contrast, specifically that where dam impacts were negligible there was no change in the LSF; and where dams impacts were more substantial we observed significant LSF changes.

We also recognize Warrick et al. (2019) may have misconstrued our interpretations regarding sand increases after the 1970s. We argued that because dams reduced the fluvial sand supply, the increase in shelf sand must have come from a non-fluvial source. In this case, the erosion of coastal areas driven by increases in wave energy (not discharge) from the Pacific climate shift in the mid-1970s. Modifications to the sediment dispersal system prevented fluvial sand from replacing sediment lost to wave-induced erosion and resuspension. Storlazzi and Reid (2010) note that fine-grained material likely remains on the $\mathrm{MB}$ shelf because losses during stormy periods are offset by new fluvial supply. Our point was that with dams preventing the fluvial resupply, the shelf sediment coarsened due to erosion and resuspension. It is important to reiterate that the post-1970s sediment deposits have unique characteristics-high total sand and LSF-that have not been observed over the past $\sim 1,000$ years. Therefore, this likely represents a unique set of conditions that had not existed prior to human modifications.

In conclusion, we again thank Warrick et al. (2019) for their comments. We do not think their suggestions are wrong per $s e$, but their points are inconsistent with our data and do not represent an improvement over our original interpretations. We welcome new data to test these interpretations.

\section{AUTHOR CONTRIBUTIONS}

All authors listed have contributed to this work, and approved it for publication.

\section{ACKNOWLEDGMENTS}

We would like to thank U.S. Geological Survey internal reviewer Christopher Smith for his constructive comments and feedback on this response article, SF, and the two reviewers. cycles on the suspended sediment load of the Salinas River, California. J. Hydrol. 525, 632-649. doi: 10.1016/j.jhydrol.2015.04.025

Gray, A. B., Warrick, J. A., Pasternack, G. B., Watson, E. B., and Goñi, M. A. (2014). Suspended sediment behavior in a coastal dry-summer subtropical catchment: effects of hydrologic preconditions. Geomorphology 214, 485-501. doi: 10.1016/j.geomorph.2014.03.009

Hapke, C. J., Reid, D., and Richmond, B. (2009). Rates and trends of coastal change in California and the regional behavior of the beach and cliff system. J. Coastal Res, 25, 603-615. doi: 10.2112/08-1006.1

Komar, P. (1996). The budget of littoral sediment: concepts and applications. Shore Beach 64, 18-26.

Office of National Marine Sanctuaries (ONMS) (2015). Monterey Bay National Marine Sanctuary Condition Report Partial Update: A New Assessment of the State of Sanctuary Resources 2015. Silver Spring, MD: U.S. Department of Commerce, National Oceanic and Atmospheric Administration, Office of National Marine Sanctuaries, 133. 
Rosenberger, K. J., Storlazzi, C. D., and Dartnell, P. (2019). Morphodynamics of a field of crescent-shaped rippled scour depressions: Northern Monterey Bay, CA. Mar. Geol. 407, 44-59. doi: 10.1016/j.margeo.2018.10.006

Starr, R. M., Cope, J. M., and Kerr, L. A. (2002). Trends in Fisheries and Fishery Resources Associated with the Monterey Bay National Marine Sanctuary From 1981-2000. California Sea Grant College Program.

Storlazzi, C. D., and Reid, J. A. (2010). The influence of El Nino-Southern Oscillation (ENSO) cycles on wave-driven sea-floor sediment mobility along the central California continental margin. Cont. Shelf Res. 30, 1582-1599. doi: 10.1016/j.csr.2010.06.004

Warrick, J. A., East, A. E., Storlazzi, C. D., and Conrad, J. E. (2019). Commentary: variability in shelf sedimentation in response to fluvial sediment supply and coastal erosion over the past 1,000 years in Monterey Bay, CA, United States. Front. Earth Sci. 7:256. doi: 10.3389/feart.2019.00256

Willis, C. M., and Griggs, G. B. (2003). Reductions in fluvial sediment discharge by coastal dams in California and implications for beach sustainability. J. Geol. 111, 167-182. doi: 10.1086/345922
Zhou, L., Liu, J., Saito, Y., Zhang, Z., Chu, H., and Hu, G. (2014). Coastal erosion as a major sediment supplier to continental shelves: example from the abandoned Old Huanghe (Yellow River) delta. Cont. Shelf Res. 82, 43-59. doi: 10.1016/j.csr.201 4.03.015

Conflict of Interest: The authors declare that the research was conducted in the absence of any commercial or financial relationships that could be construed as a potential conflict of interest.

Copyright (c) 2020 Carlin, Addison, Wagner, Schwartz, Hayward and Severin. This is an open-access article distributed under the terms of the Creative Commons Attribution License (CC BY). The use, distribution or reproduction in other forums is permitted, provided the original author(s) and the copyright owner(s) are credited and that the original publication in this journal is cited, in accordance with accepted academic practice. No use, distribution or reproduction is permitted which does not comply with these terms. 